Brit. J. vener. Dis. (1966), 42, 116.

\title{
CASE-FINDING THROUGH ANTE-NATAL SEROLOGICAL TESTS FOR SYPHILIS*
}

BY

\author{
J. A. BURGESS
}

West Riding Public Health Department, Wakefield, Yorkshire

Congenital syphilis is a preventable disease, at least in theory, if not always in practice. From the public health point of view, each case of congenital syphilis represents a failure of one of the links of the preventive chain. To avoid this, Prof. C. Fraser Brockington, who in 1950 was Medical Officer of Health of the West Riding Administrative County, introduced a case-finding method which is the subject of this paper.

In this scheme, pathologists send to the County or County Borough Medical Officer of Health (or to the venereologist who undertakes the VD preventive work on his behalf) copies of all positive or doubtful positive serological reports for syphilis on specimens of blood from antenatal patients residing in his area. There is only one omission from these copy reports; the patient's name and address is never given. On receipt of a positive report, a VD health visitor or social worker is instructed to get in touch with the doctor or ante-natal clinic medical officer whose name is given thereon. The social worker offers her services to the doctor in dealing with the patient, either by having a second specimen of blood taken as soon as possible, or, if the doctor wishes it, by arranging for the patient to be examined at a VD clinic without delay. If the patient is referred to a clinic and is found to be suffering from syphilis, the social worker is usually asked to undertake the delicate task of persuading the patient's contacts to attend for examination Finally, the venereologist informs the pathologist, in confidence, of the patient's clinic reference number and diagnosis.

If the patient is not referred to a VD clinic, the venereologist informs the pathologist of this fact.

\section{Results}

The statistics given in this paper relate to West Riding Administrative County residents only. The geographical county of the West Riding of Yorkshire has a total population of 3.7 millions, nearly 2 million people live in the eleven cities or county

\footnotetext{
* Received for publication July 5, 1965.
}

boroughs and the remainder in the Administrative County.

Although in the 15 years from 1950 to 1964 the total number of antenatal patients with positive serological tests for syphilis (STS) was 610 (Table I), the number of individuals was considerably less than this figure, because a patient who had a positive test in her first pregnancy might be reported again in each subsequent pregnancy. 499 (82 per cent.) antenatal patients with positive STS were referred to VD clinics for examination, but 111 (18 per cent.) were not so referred, either because a repeat specimen of blood gave negative STS or because the family doctor preferred to undertake the diagnosis and treatment of the patient.

\section{TABLE I}

ANTE-NATAL PATIENTS WITH POSITIVE SEROLOGICAL TESTS FOR SYPHILIS, 1950-64

\begin{tabular}{|c|c|c|c|c|}
\hline & \multirow{2}{*}{ Year } & \multicolumn{3}{|c|}{ Ante-natal Patients } \\
\hline & & $\begin{array}{l}\text { Positive } \\
\text { STS }\end{array}$ & $\begin{array}{l}\text { Referred to } \\
\text { VD Clinics }\end{array}$ & $\begin{array}{l}\text { Not referred to } \\
\text { VD Clinics }\end{array}$ \\
\hline & $\begin{array}{l}1950 \\
1951 \\
1952 \\
1953 \\
1954 \\
1955 \\
1956 \\
1957 \\
1958 \\
1959 \\
1960 \\
1961 \\
1962 \\
1963 \\
1964\end{array}$ & $\begin{array}{l}40 \\
53 \\
34 \\
60 \\
41 \\
34 \\
31 \\
41 \\
27 \\
33 \\
55 \\
40 \\
47 \\
41 \\
33\end{array}$ & $\begin{array}{l}32 \\
52 \\
32 \\
48 \\
32 \\
30 \\
26 \\
38 \\
25 \\
29 \\
35 \\
29 \\
38 \\
29 \\
24\end{array}$ & $\begin{array}{r}8 \\
1 \\
2 \\
12 \\
9 \\
4 \\
5 \\
3 \\
2 \\
4 \\
20 \\
11 \\
9 \\
12 \\
9\end{array}$ \\
\hline \multirow{2}{*}{ Total } & No. & 610 & 499 & 111 \\
\hline & Per cent. & 100 & 82 & 18 \\
\hline
\end{tabular}

449 (90 per cent.) of the 499 ante-natal patients referred to VD clinics were found to have syphilis (Table II, opposite). The other fifty patients (10 per cent.) were diagnosed as having other treponematoses or falsely positive STS. 
TABLE II

DIAGNOSIS OF 499 ANTE-NATAL PATIENTS WITH POSITIVE STS, 1950-64

\begin{tabular}{c|c|c}
\hline & \multicolumn{2}{|c|}{ Diagnosis } \\
\cline { 2 - 3 } Year & Syphilis & Not Syphilis \\
\hline 1950 & 29 & 3 \\
1951 & 49 & 3 \\
1952 & 28 & 4 \\
1953 & 40 & 8 \\
1954 & 30 & 2 \\
1955 & 24 & 6 \\
1956 & 25 & 1 \\
1957 & 35 & 3 \\
1958 & 23 & 2 \\
1959 & 26 & 3 \\
1960 & 28 & 7 \\
1961 & 29 & 0 \\
1962 & 35 & 3 \\
1963 & 26 & 3 \\
1964 & 22 & 2 \\
\hline Total & 449 & 50 \\
\hline
\end{tabular}

286 (63 per cent.) of the ante-natal patients diagnosed as syphilitic were new patients (Table III). In the first 9 years of the period reviewed there were more new patients with syphilis than old ones, but in the next 6 years the situation was reversed.

TABLE III

NEW AND OLD CASES OF SYPHILIS IN 449 ANTE-NATAL PATIENTS, 1950-64

\begin{tabular}{c|c|c}
\hline & \multicolumn{2}{|c}{ Ante-natal Patients } \\
\cline { 2 - 3 } Year & New & Old \\
\hline 1950 & 25 & 4 \\
1951 & 43 & 6 \\
1952 & 25 & 3 \\
1953 & 35 & 5 \\
1954 & 28 & 5 \\
1955 & 19 & 7 \\
1956 & 18 & 17 \\
1957 & 18 & 10 \\
1958 & 13 & 18 \\
1959 & 8 & 16 \\
1960 & 12 & 21 \\
1961 & 17 & 18 \\
1962 & 12 & 14 \\
1963 & 5 & 17 \\
1964 & 286 & 163 \\
\hline Total & & \\
\hline
\end{tabular}

In the 15 years since this case-finding method was introduced, 517 contacts of ante-natal patients were examined at VD clinics, and 77 ( 15 per cent.) of these contacts were found to have syphilis (Table IV), at least three being infants less than 1 year old.

\section{Commentary}

In the Administrative County in 1949, the year before the case-finding method was started, five infants under 1 year of age died of syphilis and a further seven were diagnosed as suffering from the disease. When investigating these cases it was discovered that one mother during her pregnancy had attended an ante-natal clinic where a blood test for
TABLE IV

CONTACTS OF SYPHILITIC ANTE-NATAL PATIENTS, 1950-64

\begin{tabular}{|c|c|c|c|c|}
\hline & \multirow{2}{*}{ Year } & \multirow{2}{*}{$\begin{array}{l}\text { No. of Contacts } \\
\text { Examined }\end{array}$} & \multicolumn{2}{|c|}{ Diagnosis } \\
\hline & & & Not Syphilis & Syphilis \\
\hline & $\begin{array}{l}1950 \\
1951 \\
1952 \\
1953 \\
1954 \\
1955 \\
1956 \\
1957 \\
1958 \\
1959 \\
1960 \\
1961 \\
1962 \\
1963 \\
1964\end{array}$ & $\begin{array}{l}57 \\
64 \\
34 \\
56 \\
46 \\
31 \\
27 \\
49 \\
23 \\
14 \\
23 \\
20 \\
18 \\
35 \\
20\end{array}$ & $\begin{array}{l}50 \\
54 \\
30 \\
46 \\
41 \\
25 \\
23 \\
41 \\
15 \\
13 \\
18 \\
19 \\
17 \\
31 \\
17\end{array}$ & $\begin{array}{r}7 \\
10 \\
4 \\
10 \\
5 \\
6 \\
4 \\
8 \\
8 \\
1 \\
5 \\
1 \\
1 \\
4 \\
3\end{array}$ \\
\hline \multirow{2}{*}{ Total } & No. & 517 & 440 & 77 \\
\hline & Per cent. & 100 & 85 & 15 \\
\hline
\end{tabular}

syphilis was taken, and the result was positive. Unfortunately, she failed to attend the clinic again and she received no anti-syphilitic treatment until after her confinement, when her baby was found to have congenital syphilis. In another similar case, a general practitioner was not informed of a positive report because of an error on the part of his secretary.

The advantages of the case-finding method here described are these:

(1) The attention of the doctor who has sent in a specimen of blood is drawn to the fact that he has an ante-natal patient with positive STS, thus preventing any risk of oversight.

(2) The visit of a VD social worker may avoid delay, especially in areas where ante-natal clinics are held once fortnightly or once monthly. Without this service 2 valuable months may elapse before the result of a confirmatory blood test is obtained.

(3) Ante-natal patients who, unexpectedly, are found to have positive STS and their contacts often present difficult medico-social problems. Most general practitioners are glad to have the help of an experienced social worker in arranging for them to be examined at special clinics.

(4) The pathologist who has undertaken the examination of the ante-natal patient's blood is ultimately informed of the outcome of the case. Hence, if a specimen of blood from the same patient in a later pregnancy is sent to his laboratory, he does not need to waste time in asking for a second specimen of blood or in forwarding the patient's serum to a Reference Laboratory. 
(5) Liaison between doctors working in the different branches (e.g. laboratory, general practitioner, public health, and hospital) of the National Health Service is stimulated and improved.

\section{Summary}

During the past 15 years, pathologists in the West Riding of Yorkshire Administrative County (population of 1.7 millions) have sent to the county venereologist copies (without the patients' names and addresses) of reports of positive serological tests for syphilis from expectant mothers. Thereafter, the county VD social workers have offered their services in dealing with these patients to the general practitioners and the ante-natal clinic medical officers. Of 610 ante-natal patients, 499 (82 per cent.) were referred to VD clinics and 449 were found to be suffering from syphilis. 517 contacts of these antenatal patients were examined and 77 ( 15 per cent.), three of whom were infants under 1 year old, were found to have syphilis.

The advantages of this case-finding method are discussed.
The writer wishes to thank all the West Riding pathologists and general practitioners who have co-operated in this preventive scheme. $\mathrm{He}$ is especially grateful to Mrs Gratton (confidential clerk-typist) and to the VD social workers of the West Riding Health Department for their assistance and their work in collecting the statistics.

\section{Le dépistage des cas de syphilis par des tests sériques prenatals \\ RÉSUMÉ}

Pendant les 15 dernières années les pathologistes du West Riding de Yorkshire Administrative County (population 1,7 million) ont envoyé au vénéréologiste du comté des copies des rapports (sans les noms et les adresses des patientes) des tests sériques positifs pour la syphilis chex les femmes enceintes. Par la suite les visiteuses sociales du service antivénérien du comté ont offert leurs services aux médecins de famille et aux médecins des dispensaires prénatals qui s'occupaient de ces femmes. Des 610 patientes prénatales, 499 ( 82 pour cent) ont été envoyées aux dispensaires antivénériens et 449 ont été trouvées atternies de syphilis. 517 contacts de ces malades prénatales ont été examinés et 77 (15 pour cent), trois d'entre eux étant des bébés âgés de moins d'un an, souffraient de la syphilis. Les avantages de cette méthode de dépistage sont discutés. 